RAfą PląseK

ORCID 0000-0003-1033-7160

Instytut Studiów Politycznych PAN

\title{
DYSKURSY PODSTAW PRZEDSIĘBIORCZOŚCI
}

AвSTRACT. Pląsek Rafał, Dyskursy podstaw przedsiębiorczości [Discourses of Entrepreneurship Education]. Studia Edukacyjne nr 58, 2020, Poznań 2020, pp. 233-245. Adam Mickiewicz University Press. ISSN 1233-6688. DOI: 10.14746/se.2020.58.12

The article discusses the discourses which describe entrepreneurship and market and state relations in the perspective of the social market economy in Polish Entrepreneurship Education textbooks. The author points out that dominant in the textbooks is the economic model of entrepreneurship. He also notes that the concept of social market economy, indicated in the Constitution of the Republic of Poland as the bedrock of the economic system, appears only in some textbooks.

Key words: Entrepreneurship Education, entrepreneurship, social market economy

\section{Wprowadzenie}

Prowadząc rozważania o naturze powiązań między edukacją i polityką, Bogusław Śliwerski zauważa, iż podręczniki szkolne i pozostałe pomoce dydaktyczne

nie są (...) jedynie tekstami kultury, w których ma miejsce odzwierciedlenie współczesnej wiedzy o świecie. Dla polityków są one przecież doskonałym źródłem, medium do przekazywania uczniom pożądanego ideologicznie systemu znaczeń i interpretacji, aby możliwa była interioryzacja systemu wartości ${ }^{1}$.

Tym bardziej że - powołując się na badania - „mamy w III RP do czynienia z dostosowywaniem podręczników szkolnych (...) do programów

${ }^{1}$ B. Śliwerski, Diagnoza uspołecznienia publicznego szkolnictwa III RP w gorsecie centralizmu, Kraków 2013, s. 221. 
kształcenia w sposób ściśle powiązany z ideologią panującej władzy”2 Mogą być więc wykorzystywane zarówno jako narzędzia poznania, jak i panowania ${ }^{3}$.

Jednym z celów nauczania podstaw przedsiębiorczości - przedmiotu obowiązkowego od roku szkolnego 2002/2003 we wszystkich typach szkół ponadgimnazjalnych - była „próba przekształcania systemu kształcenia w polskich szkołach tak, aby przekazywana wiedza miała w większym stopniu charakter aplikacyjny" ${ }^{4}$. Potrzeba rozwijania przedsiębiorczości była jednym z tematów Rad Europejskich w Sztokholmie 23-24 marca 2001 roku oraz Barcelonie 15-16 marca 2002 roku, podczas których podkreślano potrzebę uwzględniania jej w celach europejskich systemów edukacyjnych ${ }^{5}$.

Zgodnie z założeniami, edukacja przedsiębiorczości miała obejmować zarówno szkoły ponadgimnazjalne (w ramach odrębnego przedmiotu podstawy przedsiębiorczości), jak i gimnazja - tam jednak, z uwagi na włączenie $\mathrm{w}$ zakres wiedzy o społeczeństwie, kompetentne kształcenie $\mathrm{w}$ zakresie przedsiębiorczości było często utrudnione ${ }^{6}$. W szkołach ponadgimnazjalnych również pojawiały się problemy, dotyczące między innymi kształcenia nauczycieli w zakresie nauczania podstaw przedsiębiorczości oraz niepewnej „rangi" tego przedmiotu, przejawiającej się między innymi małą liczbą godzin przeznaczonych na jego realizację oraz brakiem możliwości zdawania z niego matury ${ }^{7}$.

Podstawy przedsiębiorczości to przedmiot, który domyślnie w największym stopniu odpowiada za przekazywanie uczniom szkół ponadgimnazjalnych wiedzy dotyczącej zagadnień ekonomicznych, przez co można potraktować go jako interesujące źródło informacji dotyczących charakteru wspomnianej wiedzy. W tym też kontekście chciałbym spojrzeć na podręczniki do podstaw przedsiębiorczości. W niniejszym tekście pragnę zaproponować jakościową analizę treści sześciu podręczników szkolnych do tego przedmiotu, utrzymaną w duchu teorii krytycznej ${ }^{8}$.

\section{${ }^{2}$ Tamże.}

${ }^{3}$ L. Kopciewicz, Podręczniki szkolne jako narzędzie przemocy symbolicznej, [w:] Gender w podręcznikach. Projekt badawczy. Raport, tom 1, red. I. Chmura-Rutkowska, M. Duda, M. Mazurek, A. Sołtysiak-Łuczak, Warszawa 2016, s. 82.

${ }^{4}$ M. Makieła, Z. Makieła, Nauczanie podstaw przedsiębiorczości w liceach ogólnoksztatcacych i liceach profilowanych, Przedsiębiorczość - Edukacja, 2005, 1, s. 177.

${ }^{5}$ Zalecenie Parlamentu Europejskiego i Rady z 18 grudnia 2006 r. w sprawie kompetencji kluczowych w procesie uczenia się przez całe życie (2006/962/WE), Dziennik Urzędowy Unii Europejskiej z 30.12.2006, s. L 394/10.

${ }^{6} \mathrm{M}$. Tracz, T. Rachwał, Przedmiot podstawy przedsiębiorczości. Założenia realizacji a przygotowanie nauczycieli, Przedsiębiorczość - Edukacja, 2007, 3, s. 287.

7 Tamże, s. 293.

${ }^{8}$ J.L. Kincheloe, P. McLaren, Teoria krytyczna i badania jakościowe. Rewizja, [w:] Metody badań jakościowych, tom 1, red. N.K. Denzin, Y.S. Lincoln, Warszawa 2014, s. 437-444. 
Pierwszą osią analizy uczyniłem samo zagadnienie przedsiębiorczości oraz to, jak koncepcja ta przedstawiana jest w podręcznikach; ciekawiło mnie, $\mathrm{w}$ jakich aspektach powiązane są one $\mathrm{z}$ teoretycznymi ujęciami przedsiębiorczości. Kolejna oś analizy skoncentrowana jest na zagadnieniu prezentowania w podręcznikach relacji państwa i rynku w kontekście społecznej gospodarki rynkowej. Zagadnienie to jest interesujące przynajmniej w dwóch aspektach. Po pierwsze, zgodnie z art. 20. Konstytucji Rzeczypospolitej Polskiej, podstawą ustroju gospodarczego kraju jest właśnie „społeczna gospodarka rynkowa oparta na wolności działania gospodarczej własności prywatnej oraz solidarności, dialogu i współpracy partnerów społecznych" ${ }^{\prime \prime}$. Zastanawiająca staje się więc kwestia tego, na ile prezentowane w podręcznikach relacje państwa i rynku odpowiadają założeniom społecznej gospodarki rynkowej. Po drugie zaś, zgodnie z założeniami teorii krytycznej, to między innymi właśnie w relacjach państwa i rynku ujawniać mogą się praktyki dyskursywne odpowiedzialne za dyscyplinowanie społeczeństwa ${ }^{10}$.

Wyniki zaproponowanej w pracy analizy mogą stać się użyteczne w dwójnasób: prócz wniosków dotyczących natury podręcznikowej przedsiębiorczości przedstawię również roztoczoną $\mathrm{w}$ podręcznikach wizję relacji państwa i rynku, co może stanowić cenne źródło informacji w zakresie dyskursu społeczno-ekonomicznego obecnego w polskich szkołach.

Wybierając podręczniki do analizy, starałem się uzyskać możliwie szerokie spektrum - prócz zróżnicowania w zakresie dat wydania, zdecydowanie istotniejsze było zadbanie o różnorodność wydawnictw i autorów - tak, aby $\mathrm{w}$ analizie znalazły się zarówno podręczniki opublikowane przez czołowe polskie wydawnictwa (Nowa Era, PWN, WSiP, Żak), jak i interesujące pozycje „spoza” głównego nurtu (Civitas, Key Text).

\section{Pomiędzy liberalizmem a społeczną gospodarką rynkową}

Kwestia obecności człowieka w gospodarce bezpośrednio przekłada się na problematykę relacji państwa i rynku - czyli również społecznej gospodarki rynkowej. Witold Morawski prezentuje trzy koncepcje człowieka w gospodarce: ekonomicznego, socjologicznego oraz społeczno-ekonomicznego. Jego art. 20.

${ }_{9}^{9}$ Konstytucja Rzeczypospolitej Polskiej z 2 kwietnia 1997 r. (DzU 1997, nr 78, poz. 483),

${ }^{10}$ J.H. Turner, Struktura teorii socjologicznej, red. nauk. przekł. A. Manterys, G. Woroniecka, Warszawa 2008, s. 634; P. McLaren, Critical Pedagogy and Class Struggle in the Age of Neoliberal Globalization: Notes from History's Underside, The International Journal of Inclusive Democracy, 2005, 2(1), s. 17. 
rozważania posłużą mi za punkt teoretycznego odniesienia do zagadnień poruszanych w pracy.

Człowiek ekonomiczny (homo oeconomicus) jest nastawiony na efektywność, dba o maksymalizację własnego interesu. Kieruje się racjonalnością, która jest możliwa jedynie wówczas, gdy jest on wolny, co ma gwarantować wolny rynek. W wymiarze tym koncepcja człowieka ekonomicznego jest blisko powiązana z myśleniem liberalnym i neoliberalnym ${ }^{11}$. Eugenia Potulicka i Joanna Rutkowiak, poprzez odwołania do takich klasyków koncepcji neoliberalnej jak M.N. Rothbard, M. Friedman, czy R. Nozick, charakteryzują myślenie $\mathrm{w}$ tym paradygmacie $\mathrm{w}$ następujący sposób:

- Wolny rynek rozpatrywany jest jako recepta na problemy i kryzysy. Tylko w warunkach wolności ekonomicznej (przy państwie minimalnym, funkcjonującym na zasadzie „nocnego stróża”) możliwa jest wolność polityczna i indywidualna - człowiek to podmiot ekonomiczny, „...homo oeconomicus. Dla tak postrzeganej jednostki cnotą jest egoizm i wydajność"12.

- Człowiek ponosi odpowiedzialność za swe czyny. Neoliberałowie absolutyzują teorie racjonalnego wyboru oraz dekonstytuują solidaryzm społeczny - w konsekwencji wina za niepowodzenia jednostki zrzucana jest wyłącznie na jej indywidualne wybory ${ }^{13}$.

Jednym z podstawowych założeń koncepcji neoliberalnych jest również wiara, że rynek ma zdolność samoistnej regulacji - często mówi się w tym kontekście o tak zwanej „niewidzialnej ręce rynku” ${ }^{14}$. Co interesujące, tezę o samoregulacji rynku zdemistyfikował, już w latach 40, XX wieku, Karl Polanyi ${ }^{15}$, natomiast współcześnie możemy wzmacniać jego argumentację chociażby za pomocą koncepcji zawodności rynku ${ }^{16}$.

Koncepcja człowieka socjologicznego (homo sociologicus) podkreśla zbiorowy charakter ludzkiej egzystencji, zwracając uwagę na interes grupowy oraz obowiązujące $\mathrm{w}$ grupie normy i wartości $\mathrm{i}^{17}$. W tym kontekście nawiązać warto do jednego z kluczowych podsystemów, w dużej mierze odpowiadającego za reprodukcję wspomnianych norm i wartości - mowa oczywiście o systemie edukacji. Prócz pełnienia szeregu istotnych funkcji społecznych, przekazywana w szkole wiedza, postawy i umiejętności są kluczowe dla skuteczności jakichkolwiek szerzej zakrojonych przemian społecznych, nie mówiąc już o procesie transformacji systemowej.

\footnotetext{
${ }^{11}$ W. Morawski, Socjologia ekonomiczna, Warszawa 2012, s. 25-29.

${ }^{12}$ E. Potulicka, J. Rutkowiak, Neoliberalne uwikłania edukacji, Kraków 2012, s. 47.

${ }^{13}$ Tamże, s. 44-47.

${ }^{14}$ C. Crouch, Osobliwa nie-śmierć neoliberalizmu, przekł. Ł. Dominiak, Toruń 2015, s. 44.

15 K. Polanyi, Wielka transformacja, przekł. M. Zawadzka, Warszawa 2010, s. 177.

${ }^{16}$ W. Giza, Zawodność rynku. Powstanie i rozwój idei, Kraków 2013, s. 49; J.E. Stiglitz, Ekonomia sektora publicznego, Warszawa 2013, s. 90-101.

${ }_{17}$ W. Morawski, Socjologia ekonomiczna, s. 29-32.
} 
Koncepcje homo oeconomicus oraz homo sociologicus, choć służyły i służą jako uzasadnienie dla określonych polityk społeczno-gospodarczych, są, przynajmniej w swych skrajnych wersjach, obciążone wieloma wadami. Stąd, pojawiają się u Morawskiego rozważania na temat trzeciej, mieszanej koncepcji człowieka społeczno-ekonomicznego (zakorzenionego instytucjonalnie), która w trafniejszy sposób może być odnoszona do rzeczywistości społecznogospodarczej ${ }^{18}$. Biorąc pod uwagę założenia społecznej gospodarki rynkowej, łączącej rynkową wolność z kwestiami sprawiedliwości społecznej motywowanej kolektywnie, jest ona, w pewnym sensie, odzwierciedleniem pewnego modelu człowieka społeczno-ekonomicznego.

Warto zauważyć, iż konstrukcja art. 20. Konstytucji RP poniekąd zakłada wyżej opisany model człowieka, a więc i stosunków społeczno-gospodarczych. Jak zauważa Tomasz Przybyciński, określenie ustroju gospodarczego Polski właśnie jako społecznej gospodarki rynkowej niejako nakazuje zachowanie równowagi pomiędzy wartościami wskazanymi w Konstytucji, czyli wolnością działalności gospodarczej, własnością prywatną oraz komplementarną triadą solidarności, dialogu oraz współpracy partnerów społecznych ${ }^{19}$. Sama koncepcja społecznej gospodarki rynkowej, powstała na gruncie niemieckiego ordoliberalizmu i w Niemczech wprowadzona przez Alfreda Müller-Armacka,

różniła się zdecydowanie od kapitalizmu leseferystycznego, ponieważ ład rynkowy tworzono na fundamencie wartości społecznych i socjalnych. Z kolei wolny rynek stymulował rozwój aktywności gospodarczej, co odróżniało go od projektów kolektywistycznych $^{20}$.

Koncepcja zakłada więc swego rodzaju spójność, równowagę łączących ją elementów. Polska rzeczywistość społeczna, polityczna i gospodarcza zdaje się jednak co najmniej w umiarkowanym stopniu odpowiadać idei społecznej gospodarki rynkowej ${ }^{21}$.

Jak prezentuje się $\mathrm{w}$ analizowanych podręcznikach kwestia społecznej gospodarki rynkowej ujęta w kontekście relacji państwa i rynku? Swego rodzaju podsumowanie analizy odnaleźć można w tabeli 1, przedstawiającej podstawowe, kluczowe dla podręczników spostrzeżenia we wspomnianych kwestiach. Tam, gdzie wskazać można było fragmenty tekstów bezpośrednio podsumowujące obowiązujący $\mathrm{w}$ danym podręczniku dyskurs $\mathrm{w}$ zakresie

18 Tamże, s. 34.

19 T. Przybyciński, Polityka ustrojowa w świetle polskich doświadczeń, Prace i Materiały Instytutu Rozwoju Gospodarczego SGH, 2012, 88, s. 287-288.

${ }^{20}$ Tamże, s. 290.

${ }^{21}$ K. Leśniak-Moczuk, Równość i sprawiedliwość w społecznej gospodarce rynkowej, Nierówności Społeczne a Wzrost Gospodarczy, 2004, 4, s. 235-236. 
relacji państwa i rynku - zamieszczam konkretne cytaty. W przypadku ich braku lub potrzeby swego rodzaju "dopowiedzenia" - w tabeli umieszczam również stosowne podsumowania. W zakresie nawiązań do społecznej gospodarki rynkowej $\mathrm{w}$ trzech pierwszych podręcznikach wskazuję rolę, jaka nadawana jest jej przez autorów podręczników, w kolejnych zaś - z uwagi na brak dedykowanych bezpośrednio tej charakterystyce treści - charakter nawiązań do idei społecznej gospodarki rynkowej.

Tabela 1

Relacje państwa i rynku oraz ich konsekwencje

w postaci nawiązań do społecznej gospodarki rynkowej (SGR) w podręcznikach

\begin{tabular}{|c|c|c|}
\hline Podręcznik & Relacje państwo - rynek & $\begin{array}{c}\text { Nawiązania } \\
\text { do SGR }\end{array}$ \\
\hline $\begin{array}{l}\text { Nasiłowski } \\
(2002)\end{array}$ & $\begin{array}{l}\text { Mimo nawiązań do wizji samoregulującego się } \\
\text { rynku, autor zauważa zalety progresywnego opo- } \\
\text { datkowania dochodów najwyżej zarabiających. } \\
\text { Niemniej jednak, zauważa iż „(...) głównym ce- } \\
\text { lem państwa jest wzrost gospodarczy i na tym tle } \\
\text { wzrost dobrobytu społecznego" }{ }^{22} \text {. }\end{array}$ & $\begin{array}{l}\text { Postulat uzasad- } \\
\text { niony, jednak jego } \\
\text { realizacja winna } \\
\text { być uzależniona } \\
\text { od możliwości } \\
\text { gospodarki. }\end{array}$ \\
\hline $\begin{array}{l}\text { Bielecka } \\
\text { (2005) }\end{array}$ & $\begin{array}{l}\text { Interes społeczny winien być stawiany ponad } \\
\text { ekonomicznym, „(..) zadaniem państwa jest } \\
\text { stworzenie warunków wzrostu gospodarczego, } \\
\text { który zapewni wyższe płace, lepsze warunki } \\
\text { mieszkaniowe, nowoczesne szpitale }(. . .) \text { zapew- } \\
\text { nienie wysokiego i stabilnego poziomu zatrudnie- } \\
\text { nia (...) w miarę sprawiedliwy podział dochodu } \\
\text { narodowego oraz zmniejszenie nierówności spo- } \\
\text { łecznych" }{ }^{23} \text {. }\end{array}$ & $\begin{array}{l}\text { Podstawa ustroju } \\
\text { gospodarczego, } \\
\text { podkreślenie } \\
\text { roli partnerów } \\
\text { społecznych oraz } \\
\text { zwrócenie uwagi } \\
\text { na słabość pol- } \\
\text { skich związków } \\
\text { zawodowych. }\end{array}$ \\
\hline $\begin{array}{l}\text { Red. Merta, } \\
\text { Pacewicz } \\
(2005)\end{array}$ & $\begin{array}{l}\text { Podkreślenie historycznej roli państwa opiekuń- } \\
\text { czego. } \\
\text { Próbując odpowiedzieć na pytania dotyczące kwe- } \\
\text { stii aktualnych interwencji państwa w gospodarkę } \\
\text { ważą argumenty nie udzielając jednoznacznej } \\
\text { odpowiedzi }{ }^{24} \text {. }\end{array}$ & $\begin{array}{l}\text { Definicyjnie to } \\
\text { podstawa ustroju } \\
\text { gospodarczego } \\
\text { III RP, brak jed- } \\
\text { nak rozwiniętych } \\
\text { odniesień do } \\
\text { polskiej rzeczywi- } \\
\text { stości. }\end{array}$ \\
\hline $\begin{array}{l}\text { Gregorczyk, } \\
\text { Romanow- } \\
\text { ska i in. } \\
(2007)\end{array}$ & $\begin{array}{l}\text { Propozycja zachowania względnej równowagi } \\
\text { pomiędzy państwem a rynkiem „(...) w miarę } \\
\text { rozwoju działalności gospodarczej okazało się, że } \\
\text { sam rynek nie może być ‘regulatorem' aktywno- }\end{array}$ & $\begin{array}{l}\text { Nawiązania: } \\
\text { w zakresie } \\
\text { względnej równo }\end{array}$ \\
\hline
\end{tabular}

${ }^{22}$ M. Nasiłowski, Podstawy przedsiębiorczości, Warszawa 2002, s. 181.

${ }^{23}$ M. Bielecka, Podstawy przedsiębiorczości, Warszawa 2005, s. 202.

${ }^{24}$ T. Merta, A. Pacewicz (red.), Z ekonomia na ty, Warszawa 2005, s. 178, 188. 


\begin{tabular}{|c|c|c|}
\hline $\begin{array}{l}\text { Gregorczyk, } \\
\text { Romanow- } \\
\text { ska i in. } \\
(2007)\end{array}$ & $\begin{array}{l}\text { ści ludzkiej. Pojawiła się konieczność interwencji } \\
\text { państwa, w celu zapewnienia stabilnego rozwoju } \\
\text { społeczeństw”25. Jednakże: „(...) państwo, prowa- } \\
\text { dząc politykę gospodarczą kraju, powinno podej- } \\
\text { mować tylko niezbędne działania wspomagające } \\
\text { gospodarkę"26. }\end{array}$ & $\begin{array}{l}\text { wagi w relacjach } \\
\text { pomiędzy pań- } \\
\text { stwem i rynkiem }\end{array}$ \\
\hline $\begin{array}{l}\text { Makieła, } \\
\text { Rachwał } \\
(2012)\end{array}$ & $\begin{array}{l}\text { Propozycja zachowania równowagi pomiędzy } \\
\text { państwem a rynkiem, interesem społecznym oraz } \\
\text { ekonomicznym: } \\
\text { „(..) niezależnie od wyznawanych poglądów } \\
\text { panuje powszechna zgoda co do tego, że państwo } \\
\text { powinno być odpowiedzialne za stanowienie i eg- } \\
\text { zekwowanie prawa, w szczególności w zakresie } \\
\text { ochrony własności prywatnej, która jest funda- } \\
\text { mentem gospodarki rynkowej”27. Dalej zaś „(..) } \\
\text { w powszechnej świadomości istnieje pogląd, że } \\
\text { wzrost gospodarczy kraju powinien bezpośrednio } \\
\text { przekładać się na podniesienie poziomu życia } \\
\text { obywateli”28. }\end{array}$ & $\begin{array}{l}\text { Nawiązania: } \\
\text { w zakresie } \\
\text { względnej rów- } \\
\text { nowagi w rela- } \\
\text { cjach pomiędzy } \\
\text { państwem i ryn- } \\
\text { kiem; pojawia się } \\
\text { również kwestia } \\
\text { partnerów spo- } \\
\text { łecznych. }\end{array}$ \\
\hline $\begin{array}{l}\text { Garbacik, } \\
\text { Żmiejko } \\
(2015)\end{array}$ & $\begin{array}{l}\text { Mimo nawiązań do koncepcji niewidzialnej ręki } \\
\text { rynku, zwracają uwagę na to, że państwo winno } \\
\text { realizować szereg funkcji, oraz na regulacje praw- } \\
\text { ne, które są w gospodarce niezbędne: „(...) dla } \\
\text { dobra gospodarki powinny istnieć pewne uregu- } \\
\text { lowania prawne, jednak nie mogą one nadmiernie } \\
\text { ingerować w procesy gospodarcze, np. w produk- } \\
\text { cji, handlu, usługach"29. }\end{array}$ & $\begin{array}{l}\text { Nawiązania: } \\
\text { państwo winno } \\
\text { zapewniać opiekę } \\
\text { socjalną i społecz- } \\
\text { ną oraz ułatwie- } \\
\text { nia dla przedsię- } \\
\text { biorców. }\end{array}$ \\
\hline
\end{tabular}

Źródło: opracowanie własne na podstawie analizowanych podręczników.

Zagadnienie społecznej gospodarki rynkowej zostało poruszone wprost, z poświęceniem jej konkretnego miejsca w strukturze podręcznika, w trzech z sześciu analizowanych podręczników do przedmiotu szkolnego podstawy przedsiębiorczości, przy czym dwa z nich (autorstwa Bieleckiej oraz pod redakcją Merty i Pacewicz) zawierają opisy oddające "ducha” idei społecznej gospodarki rynkowej, wskazując (przynajmniej dyskursywnie) jej konsekwencje dla rzeczywistości społeczno-gospodarczej. Przekaz pozostałych analizowanych podręczników prezentuje względną równowagę $\mathrm{w}$ relacjach pomiędzy państwem a rynkiem - przynajmniej w tym sensie, iż żaden nie

\footnotetext{
25 S. Gregorczyk i in., Przedsiębiorczość bez tajemnic, Warszawa 2007, s. 53-54.

26 Tamże, s. 80.

27 Z. Makieła, T. Rachwał, Krok w przedsiębiorczość, Warszawa 2012, s. 48.

${ }^{28}$ Tamże, s. 52.

${ }^{29}$ K. Garbacik, M. Żmiejko, Przedsiębiorczość na czasie, Warszawa 2015, s. 222.
} 
przedstawia wizji państwa libertariańskiego czy zdecydowanie liberalnego. Jednocześnie zaznaczyć należy, iż zdarza się, że poszczególne rozwiązania w zakresie danych podręczników bywają niespójne - na przykład w kwestii polityki państwa na rynku pracy, gdzie z jednej strony podkreślana jest kluczowa rola państwa, chociażby w kwestii zapobiegania bezrobociu i reagowania na nie, $\mathrm{z}$ drugiej zaś postuluje się przerzucanie kosztów pracy z przedsiębiorców na instytucje państwowe i samorządowe ${ }^{30}$.

To, że idea społecznej gospodarki rynkowej prezentowana jest wprost li tylko w części podręczników, znajduje odzwierciedlenie w opisach wzajemnych relacji państwa i rynku. Zgodnie z doktryną, społeczna gospodarka rynkowa winna zapewniać równowagę pomiędzy wolnością działalności gospodarczej, własnością prywatną oraz solidarnością, dialogiem i współpracą partnerów społecznych. Analizowane podręczniki często prezentują jednak wizję systemu, w której trzeci z prezentowanych członów jest zdecydowanie mniej istotny - naprawdę wyczerpujący opis roli partnerów społecznych we wzajemnych relacjach państwa i rynku znalazł się wyłącznie w podręczniku autorstwa Bieleckiej, zaś opisy wykraczające poza zdawkowe wspomnienia - również w podręczniku redakcji Merty i Pacewicz oraz autorstwa Makieły i Rachwała.

\section{Przedsiębiorczość oraz jej podręcznikowe inkarnacje}

Peter Drucker konceptualizuje przedsiębiorczość w kontekście działań przedsiębiorstwa i przedsiębiorcy, podkreślając, iż jest to gotowość do podejmowania i rozwiązywania problemów, cechująca się twórczością, innowacyjnością i elastycznością ${ }^{31}$. Maria Nawojczyk zwraca uwagę na jej procesualny charakter - dzięki przedsiębiorczości ,jednostki lub zespoły tworzą nowe wartości, oparte na unikatowej kombinacji posiadanych zasobów w celu wykorzystania nadarzających się w ich otoczeniu możliwości" ${ }^{32}$. Prezentuje dwa poziomy rozważań, które w niezwykle interesujący sposób przedstawiają wewnętrzną złożoność tej koncepcji oraz mnogość podejść, wedle których można ją rozważać, badać i interpretować:

- Poziom makro - dotyczy środowiska, w którym zachodzi proces przedsiębiorczości. Obejmuje perspektywę środowiskową (instytucje i normy

${ }^{30}$ M. Nasiłowski, Podstawy przedsiębiorczości, s. 106-107; K. Garbacik, M. Żmiejko, Przedsiębiorczość na czasie, Warszawa 2015, s. 200-202.

${ }^{31}$ P. Drucker, Innowacja i przedsiębiorczość. Praktyka i zasady, przekł. A. Ehrlich, Warszawa 1992, s. 34-39.

${ }^{32}$ M. Nawojczyk, Przedsiębiorczość, Kraków 2009, s. 22. 
sprzyjające przedsiębiorczości), kapitałową (zyskiwanie i gromadzenie kapitału w działalności przedsiębiorczej) oraz ekskluzywną (sprzyjające działalności przedsiębiorczej wśród grup defaworyzowanych).

- Poziom mikro - dotyczy analizy zjawisk odnoszących się do aktorów procesu przedsiębiorczości. Obejmuje koncepcje osobowości przedsiębiorczej (charakterystyki psychologiczne sprzyjające sukcesowi oraz kwestia tego, na ile można się ich nauczyć), wyczucia sytuacji rynkowej (dostrzeganie możliwości) oraz strategicznego planowania - w zakresie odwołań do teorii zarządzania w celu wskazania determinant sukcesu ${ }^{33}$.

Z uwagi na wskazaną wieloaspektowość przedsiębiorczości, badania nad nią mają charakter interdyscyplinarny. Biorąc pod uwagę procesualny i złożony charakter przedsiębiorczości, nie powinno dziwić, iż istnieje wiele modeli działań przedsiębiorczych, które można rozważać $\mathrm{w}$ ujęciu swego rodzaju wzorców i typów idealnych ukształtowanych w różnych kontekstach kulturowych. Joanna Moczydłowska i Izabela Pacewicz wymieniają:

- model oparty na katolickiej nauce społecznej - skoncentrowany między innymi na solidarności i pomocniczości, uznający kapitał ludzki za zasób ekonomiczny;

- model ukształtowany na gruncie etyki protestanckiej - kapitałowy, stawiający w centrum wolność gospodarczą, pracę traktujący jako cnotę;

- model rodzinny - rodzina jako podstawowa komórka społeczna mająca zasadniczy wpływ na decyzje przedsiębiorcze oraz będąca ich głównym beneficjentem;

- model oparty na więziach etnicznych - więzi wynikają ze wspólnych przekonań i bliskości, personalne powiązania zmniejszają niepewność trans$\operatorname{akcji}^{34}$.

Pierwszym spostrzeżeniem, które nasuwa się w kontekście analizowanych podręczników, jest to, że ich autorzy opisując przedsiębiorczość i przedsiębiorczą postawę, często nawiązują do teorii potrzeb

przedsiębiorczość nie jest celem samym w sobie, ale jest środkiem, za którego pośrednictwem jest możliwe osiągnięcie różnych celów indywidualnych człowieka oraz celów wspólnych całego społeczeństwa ${ }^{35}$, siłą napędową przedsiębiorczości są niezaspokojone potrzeby człowieka ${ }^{36}$, osoba przedsiębiorcza dzięki posiadaniu określonych cech potrafi kreować nowe potrzeby dla siebie i innych, a także zaspokajać je niezależnie od warunków otoczenia ${ }^{37}$.

\footnotetext{
33 Tamże, s. 23-26.

34 J. Moczydłowska, I. Pacewicz, Przedsiębiorczość, Rzeszów 2007, s. 22-24.

35 M. Nasiłowski, Podstawy przedsiębiorczości, s. 14.

${ }^{36}$ S. Gregorczyk i in., Przedsiębiorczość bez tajemnic, s. 5.

37 Z. Makieła, T. Rachwał, Krok w przedsiębiorczość, s. 6.
} 
Praktycznie każdy opis towarzyszący definicjom skupia się na szerokim nakreśleniu pola problemowego przedsiębiorczości.

Każdy podręcznik zawiera również wykaz od kilku do kilkunastu cech, które miałyby charakteryzować osobę przedsiębiorczą. Zdają się one sprowadzać do trzech podstawowych, wskazanych przez Nasiłowskiego, którymi są innowacyjność, aktywność oraz zaradność. Poruszając się w zakresie analizowanych podręczników, zbiorcza, syntetyczna definicja przedsiębiorczości mogłaby brzmieć następująco: to całożyciowa, użyteczna w każdej sferze życia postawa, cechująca się innowacyjnością, zaradnością oraz aktywnością, pozwalająca na zaspokajanie potrzeb, niezbędna do sprawnego funkcjonowania $\mathrm{w}$ otoczeniu społeczno-gospodarczym, przynosząca pozytywne następstwa w sferze prywatnej, gospodarczej oraz społecznej.

Przedsiębiorczość prezentowana w podręcznikach ograniczana jest do kilku wymiarów, z dość widoczną przewagą koncepcji psychologicznej (wymienianie cech osoby, osobowości przedsiębiorczej). Autorzy analizowanych podręczników zwracają również uwagę na koncepcję wyczucia sytuacji rynkowej - zauważyć można więc nadreprezentację podejść z poziomu mikro, skupiającego się na aktorach procesu przedsiębiorczości. Poziom makro, odnoszący się do środowiska, w którym zachodzi proces przedsiębiorczości, rozwijany jest zazwyczaj nie $\mathrm{w}$ kontekście samego definiowania przedsiębiorczości, a raczej w odniesieniu do szerszego opisu instytucji i procesów gospodarczych. Warto w tym kontekście zaznaczyć, iż w podręcznikach praktycznie nie jest rozwijana perspektywa ekskluzywna, ujmująca przedsiębiorczość jako formę „walki” z wykluczeniem.

W zakresie modeli przedsiębiorczości dominuje podejście ukształtowane na gruncie etyki protestanckiej, łączone z elementami modelu rodzinnego - przedsiębiorczość ma służyć rynkowemu zaspokajaniu potrzeb jednostki i jej bliskich. W odniesieniu do modelu opartego na katolickiej nauce Kościoła - w podręcznikach występują jedynie fragmentaryczne nawiązania do roli przedsiębiorczości $\mathrm{w}$ realizacji przedsięwzięć społecznych (pomijając dość enigmatycznie wspominane "cele społeczne"). W wyżej opisanym kontekście przedsiębiorczości prezentowanej w podręcznikach - skupiającej się na zaspokajaniu potrzeb poprzez uczestnictwo w procesach rynkowych - zdecydowanie bliżej jest do modelu człowieka ekonomicznego (choć występują także elementy modelu społeczno-ekonomicznego).

\section{Zakończenie}

Przedsiębiorczość - rozpatrywana nie tylko w kontekście jej konsekwencji dla rozwoju gospodarki rynkowej, ale również codziennego ludzkiego 
funkcjonowania - uważana jest za jeden z czynników determinujących jakość kapitału ludzkiego ${ }^{38}$. W ujęciu tym zdecydowanie bliżej jest jej do zagadnień stricte ekonomicznych, powiązanych z ekonomią rynkową. Przedsiębiorczość może być jednak także istotnym elementem rozwoju kapitału społecznego, na przykład $w$ ramach ekonomii społecznej ${ }^{39}$. Jakkolwiek ten społeczny wymiar przedsiębiorczości jest poruszany $\mathrm{w}$ analizowanych podręcznikach (szczególnie w podręcznikach autorstwa Bieleckiej, Makieły i Rachwała oraz pod redakcją Merty i Pacewicz), to jednak ekonomiczny, rynkowy model użyteczności dominuje w kontekście defilowania jej istoty oraz wagi. Przyczyn takiego stanu rzeczy upatrywać można między innymi w kierunku, jakim podążała polska transformacja systemowa, gloryfikująca wartości wolnorynkowe - także neoliberalne ${ }^{40}$ - oraz indywidualistyczny ład społeczny ${ }^{41}$. To zaś musiało mieć przełożenie na rzeczywistość szkolną w tym także na koncepcje i treści obecne w podręcznikach, co tłumaczyłoby koncentrację na określonej, spójnej z dyskursem społeczno-ekonomicznym, wizji przedsiębiorczości.

Podobnie tłumaczyć można to, dlaczego - mimo obecności w Konstytucji - społeczna gospodarka rynkowa, jako swego rodzaju nadrzędna zasada konstytuująca relacje państwa i rynku, nie zajmuje kluczowej pozycji we wszystkich analizowanych podręcznikach.

Skłaniałbym się również ku tezie, iż autorzy podręczników przedstawili $\mathrm{w}$ nich ład społeczno-gospodarczy w formie możliwie bliskiej temu, co zaobserwować można w przestrzeni społeczno-gospodarczej kraju. Tym bardziej że, jak zauważa badaczka, ,zapis o społecznej gospodarce rynkowej jest tylko fasadą, pod którą nie kryje się żadna treść" 42 . Społeczna gospodarka rynkowa, mimo iż zgodnie z art. 20. Konstytucji RP stanowi podstawę ustroju gospodarczego kraju, w rzeczywistości jawi się bowiem bardziej jako niezrealizowana deklaracja, niż jako termin opisujący rzeczywistość. $Z$ tego też powodu jej obecność w analizowanych podręcznikach rozpatrywać można jedynie w kategorii interesującego dodatku.

${ }^{38}$ M. Juchnowicz, Uwagi dotyczace realizacji przedmiotu podstawy przedsiębiorczości, Przedsiębiorczość - Edukacja, 2005, 1, s. 190.

${ }^{39}$ J. Hausner, N. Laurisz, Czynniki krytyczne tworzenia przedsiębiorstw społecznych. Przedsiębiorstwo społeczne. Konceptualizacja, [w:] Przedsiębiorstwa społeczne w Polsce. Teoria i praktyka, red. J. Hausner, Kraków 2008, s. 10-11.

${ }^{40}$ G. Kołodko, Sukces na dwie trzecie. Polska transformacja ustrojowa i lekcje na przyszłość, Ekonomista, 2007, 6, s. 806.

${ }^{41}$ K. Leśniak-Moczuk, Społeczna ocena transformacji systemowej w kontekście nierówności społecznych, Nierówności Społeczne a Wzrost Gospodarczy, 2007, 10, s. 160.

${ }_{42}$ U. Zagóra-Jonszta, Społeczna gospodarka rynkowa a polska transformacja, [w:] Funkcjonowanie gospodarki polskiej po 20 latach transformacji, red. D. Kopycińska, Szczecin 2009, s. 89. 


\section{BIBLIOGRAFIA}

Crouch C., Osobliwa nie-śmierć neoliberalizmu, przekł. Ł. Dominiak, Wydawnictwo Naukowe Uniwersytetu Mikołaja Kopernika, Toruń 2015.

Drucker P., Innowacja i przedsiębiorczość. Praktyka i zasady, przekł. A. Ehrlich, Państwowe Wydawnictwo Ekonomiczne, Warszawa 1992.

Giza W., Zawodność rynku. Powstanie i rozwój idei, Wydawnictwo Uniwersytetu Ekonomicznego w Krakowie, Kraków 2013.

Hausner J., Laurisz N., Czynniki krytyczne tworzenia przedsiębiorstw społecznych. Przedsiębiorstwo społeczne. Konceptualizacja, [w:] Przedsiębiorstwa społeczne w Polsce. Teoria i praktyka, red. J. Hausner, Uniwersytet Ekonomiczny w Krakowie, Kraków 2008.

Juchnowicz M., Uwagi dotyczace realizacji przedmiotu podstawy przedsiębiorczości, Przedsiębiorczość - Edukacja, 2005, 1.

Kincheloe J. L., McLaren P., Teoria krytyczna i badania jakościowe. Rewizja, [w:] Metody badań jakościowych, tom 1, red. N.K. Denzin, Y.S. Lincoln, Wydawnictwo Naukowe PWN, Warszawa 2014.

Kołodko G., Sukces na dwie trzecie. Polska transformacja ustrojowa i lekcje na przyszłość, Ekonomista, 2007, 6.

Konstytucja Rzeczypospolitej Polskiej z 2 kwietnia 1997 r. (DzU 1997, nr 78, poz. 483).

Kopciewicz L., Podręczniki szkolne jako narzędzie przemocy symbolicznej, [w:] Gender w podręcznikach. Projekt badawczy. Raport, tom 1, red. I. Chmura-Rutkowska, M. Duda, M. Mazurek, A. Sołtysiak-Łuczak, Fundacja Feminoteka, Warszawa 2016.

Leśniak-Moczuk K., Równość i sprawiedliwość w społecznej gospodarce rynkowej, Nierówności Społeczne a Wzrost Gospodarczy, 2004.

Leśniak-Moczuk K., Społeczna ocena transformacji systemowej w kontekście nierówności społecznych, Nierówności Społeczne a Wzrost Gospodarczy, 2007, 10.

Makieła M., Makieła Z., Nauczanie podstaw przedsiębiorczości w liceach ogólnokształcacych i liceach profilowanych, Przedsiębiorczość - Edukacja, 2005, 1.

McLaren P., Critical Pedagogy and Class Struggle in the Age of Neoliberal Globalization: Notes from History's Underside, The International Journal of Inclusive Democracy, 2005, 2(1).

Moczydłowska J., Pacewicz I., Przedsiębiorczość, Wydawnictwo Oświatowe FOSZE, Rzeszów 2007.

Morawski W., Socjologia ekonomiczna, Wydawnictwo Naukowe PWN, Warszawa 2012.

Nawojczyk M., Przedsiębiorczość, Zakład Wydawniczy Nomos, Kraków 2009.

Polanyi K., Wielka transformacja, przekł. M. Zawadzka, Wydawnictwo Naukowe PWN, Warszawa 2010.

Potulicka E., Rutkowiak J., Neoliberalne uwiktania edukacji, Oficyna Wydawnicza Impuls, Kraków 2012.

Przybyciński T., Polityka ustrojowa w świetle polskich doświadczeń, Prace i Materiały Instytutu Rozwoju Gospodarczego SGH, 2012, 88.

Stiglitz J. E., Ekonomia sektora publicznego, Wydawnictwo Naukowe PWN, Warszawa 2013.

Śliwerski B., Diagnoza uspołecznienia publicznego szkolnictwa III RP w gorsecie centralizmu, Oficyna Wydawnicza Impuls, Kraków 2013.

Tracz M., Rachwał T., Przedmiot podstawy przedsiębiorczości. Założenia realizacji a przygotowanie nauczycieli, Przedsiębiorczość - Edukacja, 2007, 3.

Turner J. H., Struktura teorii socjologicznej, red. nauk. przekł. A. Manterys, G. Woroniecka, Wydawnictwo Naukowe PWN, Warszawa 2008. 
Zagóra-Jonszta U., Społeczna gospodarka rynkowa a polska transformacja, [w:] Funkcjonowanie gospodarki polskiej po 20 latach transformacji, red. D. Kopycińska, Katedra Mikroekonomii Uniwersytetu Szczecińskiego, Szczecin 2009.

Zalecenie Parlamentu Europejskiego i Rady z 18 grudnia 2006 r. w sprawie kompetencji kluczowych w procesie uczenia się przez całe życie (2006/962/WE), Dziennik Urzędowy Unii Europejskiej z 30.12.2006, L 394/10.

\section{Analizowane podręczniki}

Bielecka M., Podstawy przedsiębiorczości, Wydawnictwo Akademickie Żak, Warszawa 2005. Garbacik K., Żmiejko M., Przedsiębiorczość na czasie, Wydawnictwo Naukowe PWN, Warszawa 2015.

Gregorczyk S., Romanowska M., Sopińska A., Wachowiak P., Przedsiębiorczość bez tajemnic, Wydawnictwa Szkolne i Pedagogiczne, Warszawa 2007.

Makieła Z., Rachwał T., Krok w przedsiębiorczość, Wydawnictwo Nowa Era, Warszawa 2012. Merta T., Pacewicz A. (red.), Z ekonomia na ty, Wydawnictwo Civitas, Warszawa 2005. Nasiłowski M., Podstawy przedsiębiorczości, Wydawnictwo Key Text, Warszawa 2002. 